\title{
PENGARUH PERHATIAN ORANG TUA DAN PERSEPSI ATAS KOMPETENSI GURU TERHADAP PRESTASI BELAJAR SOSIOLOGI (SURVEY PADA SISWA SMAN DI KOTA TANGERANG)
}

\author{
Ike Hilatun Nisa \\ STAI Asy-Syukriyyah Tangerang \\ Ike.hilatunnisa@asy-syukriyyah.ac.id
}

\begin{abstract}
This study is a survey and aims to find and analyze empirically the influence of parental attention on Sociology learning achievement, perceptions of teacher competence on Sociology learning achievement, the influence of parental attention and jointly on Sociology learning achievement. The research method used was a survey. Affordable population in this study were students of class XI in 4 public high schools in Tangerang City with a sample of 85 students. The research sample was obtained through a simple random sampling method in which the researcher mixed subjects in the population so that all subjects were considered equal. Data collection using instruments: questionnaires, and the collection of students' report cards Sociology. The collected data is then analyzed using correlation and multiple regression techniques. Before the data is analyzed, a descriptive statistical analysis and a data requirements test (normality test and linearity test) are conducted before the regression test is performed. This research was conducted in March 2016 to June 2016. The results showed that: 1) There was a significant influence of parents' attention (X1) and perceptions of teacher competence (X2) on sociology learning achievement $(Y)$, this was evidenced by the value sig. 0,000 $<0.05$ and Fcount $=28,123.2)$ There is a significant influence of parents' attention (X1) on the learning achievements of Sociology $(Y)$, this is evidenced by the value of sig. 0,000 $<0.05$ and tcount $=5.210 .3)$ There is a significant influence of perception on teacher competence $(X 2)$ on the learning achievement of Sociology $(Y)$, this is evidenced by the sig.0,000 value $<0.05$ and tcount $=5,400$. The resulting regression equation is $Y=$ $29,935+0,191 X 1+0,274 X 2$.
\end{abstract}

Keywords: Parental Attention, Perception of Teacher Competence and Learning Achievement in Sociology

\section{PENDAHULUAN}

Belajar akan lebih bermakna jika siswa mengalami apa yang dipelajarinya bukan mengetahuinya. Seorang siswa yang telah mengalami proses belajar akan mengalami perubahan dalam dirinya, pengalaman belajar siswa akan meningkatkan kemampuan kompetensinya lebih dari sebelumnya. Untuk mengetahui seberapa tinggi tingkat keberhasilan dalam proses belajar tersebut, maka dapat dilihat dari Prestasi belajarnya. Prestasi belajar adalah hasil terakhir proses pembelajaran yang telah diikuti oleh siswa.

Prestasi belajar setiap siswa disemua jenjang sangat perlu untuk ditingkatkan, terutama bagi Siswa SMA Negeri di kota Tangerang yang mempelajari Sosiologi. Dengan hasil belajar yang tinggi, Siswa akan memperoleh perhatian yang tinggi terhadap bidang studi Sosiologi. Perkembangan yang pesat di era globalisasi teknologi komunikasi dan informasi, 
memacu semakin ketatnya kompetisi dalam dunia pekerjaan. Hal ini memotivasi siswa untuk semakin meningkatkan ilmu pengetahuan yang dimilikinya agar dapat mengikuti perkembangan komunikasi dan informasi serta dapat bersaing dalam memperoleh lapangan pekerjaan.

Mata pelajaran Sosiologi merupakan bagian dari pelajaran rumpun IPS, yang seringkali masih dirasakan sebagai pelajaran yang membosankan dan kurang menarik, karena dianggap sebagai mata pelajaran hafalan. Berkenaan dengan pelajaran Sosiologi tersebut, ternyata paradigma belajar sosiologi memiliki relevansi dengan prestasi belajar siswa. Hal ini, dapat dibuktikan dengan prestasi belajar Sosiologi siswa kelas XI IPS SMA Negeri Tangerang, masih kurang optimal. Fakta di lapangan, rata-rata nilai siswa pada saat Ulangan Tengah Semester (UTS) tahun pelajaran 2015-2016 sebesar 75,42 dibawah nilai Ketuntasan Minimum (KKM) yaitu sebesar 78, tetapi masih belum dapat menunjukkan nilai yang di atas nilai KKM seperti yang diharapkan. Ketercapaian KKM sebesar 55,56\% dengan nilai tertinggi 86,5 dan nilai terendah 52,75 .

Ada dua factor penting dalam hal ketercapaian prestasi belajat siswa tersebut. Faktor yang pertama adalah kompetensi guru. Kompetensi guru berperan dalam kegiatan belajar mengajar, interaksi antara guru dan anak didik merupakan kegiatan yang dominan. Kegiatan itu melibatkan komponen-komponen yang antara satu dengan yang lainnya saling menyesuaikan dan menunjang dalam pencapaian tujuan belajar bagi anak didik. Dari konsep di atas, jelaslah bahwa kompetensi guru adalah suatu unsur yang sangat berpengaruh terhadap keberhasilan belajar siswa. Dengan demikian kompetensi guru merupakan salah satu unsur yang tidak bisa diabaikan dalam pengelolaan proses interaksi belajar mengajar.

Sedangkan factor kedua adalah perhatian orang tua, dimana, orang tua merupakan pendidik utama dan pertama bagi anak-anaknya. Orang tualah yang menyebabkan anak itu ada dan setelah anak itu lahir ke dunia, orang yang pertama sekali dikenal oleh seorang anak adalah orang tua. Orang tua juga lebih sering bertemu dengan anak-anaknya dalam kehidupan sehari-hari. Oleh karena itu, pendidikan dari orang tua menjadi dasar perkembangan dan kehidupan anak di kemudian hari.

Berdasarkan uraian permasalahan di atas maka perhatian orang tua dan persepsi atas kompetensi guru diduga memiliki pengaruh terhadap prestasi belajar Sosiologi dimana tujuan penelitian ini adalah untuk mengetahui "Pengaruh Perhatian Orang Tua dan Persepsi Atas Kompetensi Guru Terhadap Prestasi Belajar Sosiologi Siswa SMA Negeri Di Kota Tangerang Banten." 


\section{KAJIAN TEORI}

\section{Prestasi Belajar}

Wahab dalam Syafi'I dkk menjelaskan istilah prestasi belajar terdiri dari dua kata, yaitu prestasi dan belajar. Istilah prestasi di dalam Kamus Ilmiah Populer didefinisikan sebagai hasil yang telah dicapai. Menurut Noehi Nasution, menyimpulkan bahwa "belajar dalam arti luas dapat diartikan sebagai suatu proses yang memungkinkan timbulnya atau berubahnya suatu tingkah laku sebagai hasil dari terbentuknya respons utama, dengan syarat bahwa perubahan atau munculnya tingkah baru itu bukan disebabkan oleh adanya perubahan sementara karena sesuatu hal. ${ }^{1}$

Dalam istilah lain, prestasi belajar sering kali disandingkan dengan istilah prestasi akademi. Hal ini sejalan dengan Bossaert, Doumen, Buyse dan Verschueren Menjelaskan bahwa prestasi akademis sebagai keberhasilan siswa dalam memenuhi tujuan jangka pendek atau panjang dalam pendidikan. Lassiter melihat prestasi akademik siswa sebagai kinerja siswa yang kuat di bidang akademik tertentu. Sedangkan Good dan Chien berpendapat bahwa prestasi belajar adalah perolehan pengetahuan atau keterampilan yang dikembangkan oleh materi pelajaran, biasanya ditunjukkan dengan nilai tes atau nilai numeric yang ditugaskan oleh guru. ${ }^{2}$ Berdasarkan penjelasan di atas dapat disimpulkan bahwa prestasi belajar adalah sebuah hasil akademik yang diperoleh oleh seorang siswa setelah mereka melakukan proses pembelajaran selama satu semester.

Keberhasilan sebuah prestasi belajar dapat dipengaruhi oleh berberapa faktor. Adapun faktor-faktor itu, menurut Ngalim Purwanto dalam aris dapat kita bedakan menjadi dua golongan (a) faktor yang ada pada diri organisme itu sendiri yang kita sebut faktor individual, dan (b) faktor yang ada di luar individu yang kita sebut faktor sosial. Yang termasuk ke dalam faktor indivual antara lain: faktor kematangan/ pertumbuhan, kecerdasan, latihan, motivasi dan faktor pribadi. Sedangkan yang termasuk faktor sosial antara lain: faktor keluarga, guru dan cara mengajarnya, alat-alat yang dipergunakan dalam belajar-mengajar, dan motivasi sosial. ${ }^{3}$

\footnotetext{
1 Ahmad Syafi' dkk . Studi Tentang Prestasi Belajar Siswa Dalam Berbagai Aspek Dan Faktor Yang Mempengaruhi. Jurnal Komunikasi Pendidikan, 2(2). h. 117.

${ }^{2}$ Sofwan Adiputra \& Mujiyati. 2017. Motivasi dan Prestasi Belajar Siswa di Indonesia: Kajian Meta-Analisis, Jurnal KONSELOR 6 (4). h. 151.

3 Aris Setyawan, Pengaruh Persepsi Atas Kompetensi Guru Dan Peran Orang Tua Terhadap Prestasi Belajar Bahasa Inggris (Survey Pada MTs Swasta Di Kabupaten Tangerang). 2017. Jurnal pendidikan STKIP Kusumanegara. 8 (2) . h. 3
} 


\section{Persepsi Kompetensi Guru}

Slameto dalam aris menjelaskan bahwa persepsi adalah proses yang menyangkut masuknya pesan atau informasi ke dalam otak manusia. Melalui persepsi manusia terus menerus mengadakan hubungan dengan lingkungannya. Hubungan ini dilakukan lewat inderanya, yaitu indera penglihatan, pendengaran, peraba, perasa, dan pencium. ${ }^{4}$

Selanjutnya, kompetensi guru diartikan sebagai penguasaan terhadap suatu tugas (mengajar dan mendidik), keterampilan, sikap, dan apresiasi yang diperlukan untuk menunjang keberhasilan proses pembelajaran yang dilakukannya. Dengan demikian, kompetensi yang dimiliki oleh setiap guru akan menunjukkan kualitas guru yang sebenarnya. Kompetensi tersebut akan diwujudkan dalam bentuk penguasaan ketrampilan, pengetahuan maupun sikap profesional dalam menjalankan tugas dan fungsi sebagai guru. ${ }^{5}$ Dengan demikian persepsi atas kompetensi guru adalah pandangan atau penilaian terhadap kemampuan guru dalam menjalankan tugas mengajar dan mendidik.

Kompetensi guru menurut Peraturan Pemerintah (PP) No. 19 Tahun 2005 tentang Standar Nasional Pendidikan, pemerintah telah merumuskan empat jenis kompetensi guru, adalah sebagai berikut:

a. Kompetensi Pedagogik, yaitu merupakan Kemampuan dalam pengelolaan peserta didik yang meliputi; a) pemahaman wawasan atau landasan kependidikan; b) pemahaman terhadap peserta didik; c) pengembangan kurikulum/silabus; d) perancangan pembelajaran; e) pelakanaan pembelajaran yang mendidik dan dialogis; f) evaluasi hasil belajar; dan g) pengembangan peserta didik untuk mengaktualisasikan berbagai potensi yang dimilikya.

b. Kompetensi Kepribadian, yaitu Kemampuan kepribadian yang: a) berakhlak mulia; b) mantap, stabil, dan dewasa; c) arif dan bijaksana; d) menjadi teladan; e) mengavaluasi kinerja sendiri; f) mengembangkan diri; dan g) religius.

c. Kompetensi Sosial merupakan kemampuan pendidik sebagai bagian dari masyarakat untuk: a) berkomunikasi lisan dan tulisan; b) menggunakan teknologi komunikasi dan informasi secara fungsional; c) bergaul secara efektif dengan peserta didik, sesama pendidik, tenaga kependidikan, orangtua/wali peserta didik; dan d) bergaul secara santun dengan masyarakat sekitar.

\footnotetext{
${ }^{4}$ Aris Setyawan, Pengaruh Persepsi Atas Kompetensi Guru Dan Peran Orang Tua Terhadap Prestasi Belajar Bahasa Inggris (Survey Pada MTs Swasta Di Kabupaten Tangerang). 2017 Jurnal pendidikan STKIP Kusumanegara. 8 (2). h. 4

${ }^{5}$ Cut Fitriani. 2017, Kompetensi Profesional Guru Dalam Pengelolaan Pembelajaran Di MTs Muhammadiyah Banda Aceh. Jurnal Magister Administrasi Pendidikan Pascasarjana Universitas Syiah Kuala. 5(2). hal. 89-90.
} 
d. Kompetensi Profesional yaitu kemampuan penguasaan materi pembelajaran secara luas dan mendalam yang meliputi: a) konsep, struktur, dan metode keilmuan/teknologi/seni yang menaungi/koheren dengan materi ajar; b) materi ajar yang ada dalam kurikulum sekolah; c) hubungan konsep antarmata pelajaran terkait; d) penerapan konsep keilmuan dalam kehidupan sehari-hari; dan e) kompetisi secara profesional dalam konteks global dengan tetap melestarikan nilai dan budaya nasional. ${ }^{6}$

\section{Perhatian Orang Tua}

Berdasarkan pendapat Dalyono dan Slameto tentang perhatian orang tua terhadap kegiatan belajar anak dapat berupa pemberian bimbingan dan nasihat, pengawasan terhadap belajar anak, pemberian penghargaan dan hukuman, pemenuhan kebutuhan belajar, menciptakan suasana belajar yang tenang dan tenteram, memperhatikan kesehatan anak, memberikan petunjuk praktis,mengenai (cara belajar, cara mengatur waktu, disiplin belajar konsentrasi dan persiapan menghadapi ujian).

1) Pemberian bimbingan dan nasihat Bimbingan adalah bantuan yang diberikan kepada individu tertentu. Dari definisi bimbingan tersebut dapat dikaitkan dengan bimbingan orang tua kepada anak, bahwa bimbingan adalah bantuan yang diberikan orang tua kepada anaknya untuk memecahkan masalah-masalah yang dihadapinya

2) Pengawasan terhadap belajar Orang tua perlu mengawasi pendidikan anak-anaknya, sebab tanpa adanya pengawasan yang komitmen dari orang tua besar kemungkinan pendidikan anak tidak akan berjalan lancar. Pengawasan orang tua tersebut berarti mengontrol atau mengawasi semua kegiatan atau aktivitas yang dilakukan oleh anak baik secara langsung maupun tidak langsung.

3) Pemberian penghargaan dan hukuman Yang harus diperhatikan oleh orang tua adalah memberikan pujian dan penghargaan pada kemampuan atau prestasi yang diperoleh anak. Pujian dimaksudkan menunjukan bahwa orang tua menilai dan menghargai tindakan usahanya.

4) Pemenuhan kebutuhan belajar Kebutuhan belajar adalah segala alat dan sarana yang diperlukan untuk menunjang kegiatan belajar anak. Kebutuhan tersebut bisa berupa ruang belajar anak, seragam sekolah, buku-buku, alatalat belajar dan lain-lain.

\footnotetext{
${ }^{6}$ Darliana Sormin. 2016. Kompetensi Guru Dalam Melaksanakan Dan Mengelola Proses Belajar Mengajar Di Pondok Pesantren Darul Mursyidi Desa Sialogo Tapanuli Selatan. FITRAH 02 (1). h. 120-121.
} 
5) Menciptakan suasana belajar yang tenang dan tenteram Orang tua harus menciptakan ruang dan suasana rumah yang aman dan nyaman ketika anak belajar di rumah, sehingga anak dalam belajar tidak terganggu. Suasana rumah yang gaduh dan ramai tidak akan memberi ketenangan kepada anak yang sedang belajar.

6) Memperhatikan kesehatan Orang tua harus memperhatikan makanan yang dimakan anak, gizi makanan yang diberikan, istirahat anak, dan kesehatan badan yang lainnya.

7) Memberikan petunjuk-petunjuk praktis mengenai : a) cara belajar, b) cara mengatur waktu, c) disiplin belajar, d) konsentrasi, dan e) persiapan menghadapi ujian. ${ }^{7}$

\section{METODE PENELITIAN}

Metode penelitian yang digunakan pada penelitian ini adalah penelitian survei. Penelitian survey merupakan suatu bentuk aktifitas yang sudah menjadi kebiasaan pada masyarakat, dan banyak diantaranya berpengalaman dengan riset ini sebagai suatu bentuk yang tersendiri atau yang lainnya. Survey riset dikembangkan sebagai bentuk pendekatan positivist pada ilmu-ilmu sosial. Sebagaimana dikatakan oleh Robert Groves, seorang ahli survey terkemuka, "survey menghasilkan informasi yang secara alami bersifat statistik". Survey merupakan bentuk dasar kuantitatif'. Penelitian survey menanyakan kepada beberapa responden tentang kepercayaannya, pendapat-pendapat, karakteristik, dan perilaku yang telah atau sedang terjadi. ${ }^{8}$

Penelitian ini dilakukan di Sekolah Menengah Atas Negeri yang terletak di Kota Tangerang, yaitu SMAN 2, SMAN 4, SMAN 7, SMAN 14. Waktu penelitian dijadwalkan untuk dimulai pada bulan Maret 2016 hingga Juni 2016. Populasi target penelitian ini adalah siswa/siswi seluruh SMA Negeri di Kota Tangerang pada tahun pelajaran 2015/2016 yang terdiri dari seluruh siswa/siswi kelas XI SMA Negeri di kota yang sama. Berikut ini adalah paparan jumlah siswa.

\footnotetext{
${ }^{7}$ Yuli Hendriani Dan Bustari Muchtar. 2015. Pengaruh Perhatian Orang Tua Dan Konsep Diri Terhadap Prestasi Belajar Siswa Mata Pelajaran Produktif Akuntansi Pada Smk Di Kota Payakumbuh. Jurnal Kajian Pendidikan Ekonomi. 2 (1). h. 4-5.

${ }^{8}$ F.C. Susila Adiyanta. 2019. Hukum dan Studi Penelitian Empiris: Penggunaan Metode Survey sebagai Instrumen Penelitian Hukum Empiris. Adminitrative Law \& Governance Journal. 2 (4). h. 700.
} 
Tabel 3.2

Sebaran Populasi Target

\begin{tabular}{|c|l|c|}
\hline No & \multicolumn{1}{|c|}{ Nama Sekolah } & Populasi Kelas XI \\
\hline 1 & SMAN 2 Tangerang & 140 \\
\hline 2 & SMAN 4 Tangerang & 112 \\
\hline 3 & SMAN 7 Tangerang & 119 \\
\hline 4 & SMAN 14 Tangerang & 130 \\
\hline \multicolumn{2}{r|}{ Jumlah Siswa } & 501 \\
\hline
\end{tabular}

Populasi yang diambil secara random sampling sebanyak $10 \%$ sebagai sampel penelitian. Maka, penetapannya terdapat 85 orang siswa sebagai responden/sampel penelitian ini dengan menggunakan Rumus Slovin

\section{Rumus Slovin}

$$
\mathrm{n}=\frac{\mathrm{N}}{1+N \cdot \varepsilon^{2}}
$$

$$
\begin{aligned}
& \text { Ket : } \mathrm{n} \quad \text { : Ukuran sampel } \\
& \mathrm{N} \quad \text { : Ukuran populasi } \\
& \varepsilon \quad \text { : Persen kelonggaran ketidak telitian karena kesalahan yang masih } \\
& \text { ditolerin atau dinginkan yaitu } 10 \% \text {. } \\
& n=\frac{\mathrm{N}}{1+\mathrm{N} \cdot \varepsilon^{2}} \\
& n=\frac{501}{1+(501)(0,1)^{2}} \\
& n=\frac{501}{1+(501)(0,01)} \\
& n=\frac{501}{1+5,01} \\
& n=\frac{501}{6,01} \\
& n=83,36 \\
& \text { dibulatkan }=85 \\
& n=85 \text { responden }
\end{aligned}
$$




\section{PEMBAHASAN}

Dalam penelitian ini perhitungan hipotesis dilakukan menggunakan SPSS. Hasil perhitungan dan pengujian dapat dilihat secara berurutan pada Tabel 2, Tabel 3 dan Tabel 4 yang disajikan berikut ini:

\section{Tabel 2}

\section{Hasil Perhitungan Koefisien Korelasi Pengaruh}

Variabel Pengaruh perhatian orang tua $\left(\mathrm{X}_{1}\right)$ dan Persepsi atas kompetensi guru tua $\left(X_{2}\right)$ terhadap Variabel Prestasi belajar Sosiologi (Y)

Model Summary

\begin{tabular}{|c|c|c|c|c|c|c|c|c|c|}
\hline \multirow[t]{2}{*}{ Model } & \multirow[t]{2}{*}{$\mathrm{R}$} & \multirow{2}{*}{$\begin{array}{c}\mathrm{R} \\
\text { Square }\end{array}$} & \multirow{2}{*}{$\begin{array}{l}\text { Adjusted R } \\
\text { Square }\end{array}$} & \multirow{2}{*}{$\begin{array}{l}\text { Std. Error of the } \\
\text { Estimate }\end{array}$} & \multicolumn{5}{|c|}{ Change Statistics } \\
\hline & & & & & $\begin{array}{l}\text { R Square } \\
\text { Change }\end{array}$ & $\begin{array}{c}\mathrm{F} \\
\text { Change }\end{array}$ & df1 & df2 & $\begin{array}{c}\text { Sig. F } \\
\text { Change }\end{array}$ \\
\hline 1 & $.638^{a}$ & .407 & .392 & 3.39135 & .407 & 28.123 & 2 & 82 & .000 \\
\hline
\end{tabular}

a. Predictors: (Constant), x2, x1

b. Dependent Variable: $y$

\section{Tabel 3}

Rekapitulasi Hasil Perhitungan Pengujian Signifikansi Koefisien Regresi Pengaruh

Variabel Pengaruh perhatian orang tua $\left(\mathrm{X}_{1}\right)$ dan Persepsi atas kompetensi guru $\left(\mathrm{X}_{2}\right)$ terhadap Variabel Prestasi belajar Sosiologi (Y)

ANOVA $^{\mathrm{a}}$

\begin{tabular}{|c|c|c|c|c|c|c|}
\hline \multicolumn{2}{|c|}{ Model } & Sum of Squares & Df & Mean Square & $F$ & Sig. \\
\hline \multirow{3}{*}{1} & Regression & 646.896 & 2 & 323.448 & 28.123 & $.000^{\mathrm{b}}$ \\
\hline & Residual & 943.104 & 82 & 11.501 & & \\
\hline & Total & 1590.000 & 84 & & & \\
\hline
\end{tabular}

a. Dependent Variable: $y$

b. Predictors: (Constant), x2, x1 


\section{Tabel 4}

\section{Rekapitulasi Hasil Perhitungan Persamaan Garis Regresi Pengaruh Variabel Pengaruh perhatian orang tua $\left(\mathrm{X}_{1}\right)$ dan Persepsi atas kompetensi guru $\left(\mathrm{X}_{2}\right)$ terhadap Variabel prestasi belajar Sosiologi (Y)}

Coefficients $^{\mathrm{a}}$

\begin{tabular}{|l|r|r|r|r|r|}
\hline \multirow{2}{*}{ Model } & \multicolumn{2}{|l|}{ Unstandardized Coefficients } & Standardized Coefficients & \multirow{2}{*}{ Sig. } \\
\cline { 2 - 4 } & \multicolumn{1}{|c|}{ B } & Std. Error & Beta & & \\
\hline (Constant) & 29.935 & 6.762 & & 4.427 & .000 \\
1 Perhatian Orang Tua & .191 & .037 & .443 & 5.210 & .000 \\
Persepsi atas Kompetensi Guru & .274 & .051 & .459 & 5.400 & .000 \\
\hline
\end{tabular}

Berdasarkan tabel di atas diperoleh hasil sebagai berikut:

1. Terdapat pengaruh yang signifikan perhatian orang tua dan persepsi atas kompetensi guru secara bersama-sama terhadap prestasi belajar Sosiologi siswa SMA Negeri di Kota Tangerang. Hal ini dibuktikan dengan nilai Sig. $0,000<0,05$ dan $F_{\text {hitung }}=28,123$. Sehingga dapat dipahami bahwa semakin baik perhatian dan persepsi guru maka akan semakin baik prestasi belajar siswa.

2. Terdapat pengaruh yang signifikan perhatian orang tua terhadap prestasi belajar Sosiologi siswa SMA Negeri di Kota Tangerang. Hal ini dibuktikan dengan nilai Sig. 0,000<0,05 dan $t_{\text {hitung }}=5,210$. Sehingga dapat dipahami bahwa semakin tinggi perhatian orang tua maka akan semakin baik prestasi belajar siswa.

3. Terdapat pengaruh yang signifikan persepsi atas kompetensi guru terhadap prestasi belajar Sosiologi siswa SMA Negeri di Kota Tangerang. Hal ini dibuktikan dengan nilai Sig. $0,000<0,05$ dan $t_{\text {hitung }}=5,400$. Sehingga semakin baik persepsi atas kompetensi guru maka akan semakin baik prestasi belajar siswa.

\section{KESIMPULAN}

Berdasarkan penelitian ini dapat disimpulkan bahwa variable perhatian orang tua dan variabel persepsi atas kompetensi guru merupakan varibel penting dalam hal meningkatkan prestasi belajar seorang siswa di sekolah khususnya pada mata pelajaran Sosiologi. Karena berdasarkan hasil penelitian ini menunjukan bahwa kedua varibel tersebut memiliki pengaruh yang signifikan terhadap prestasi belajar Sosiologi. 
Berdasarkan simpulan yang telah dikemukakan di atas, dapat diajukan beberapa saran sebagai berikut:

1. Dalam upaya meningkatkan prestasi belajar Sosiologi hendaknya lebih meningkatkan perhatian orang tua dan kompetensi guru dalam mata pelajaran Sosiologi. Upaya yang dilakukan dengan memperbaiki dan meningkatkan prestasi belajar Sosiologi, serta mempertimbangkan berbagai indikator yang berhubungan dengan upaya peningkatan prestasi belajar Sosiologi seperti, meningkatkan latihan-latihan yang bervariasi dalam ruang kelas.

2. Untuk meningkatkan prestasi belajar Sosiologi sangat tergantung pada peran aktif orang tua dalam menaikkan prestasi belajar Sosiologi. Untuk itu hendaknya orang tua mampu berperan aktif dalam memberikan perhatian yang dapat menstimulasi semangat belajar siswa sehingga mendapatkan prestasi belajar yang optimal.

3. Guru hendaknya lebih memperhatikan kompetensi dirinya sewaktu mendidik siswa dalam mata pelajaran Sosiologi. Dengan demikian, diharapkan akan membantu siswa meningkatan prestasi belajarnya. Oleh sebab itu peningkatkan kompetensi guru dalam mengajar Sosiologi perlu diperhatikan dan diprioritaskan.

4. Sebaiknya dibangun sinergi yang positif dan kuat antara guru, sekolah dan orang tua siswa, agar dapat meningkatkan prestasi belajar Sosiologi siswa secara optimal.

5. Penelitian ini masih sangat terbatas baik keluasan maupun kedalamannya, maka perlu diadakan penelitian lebih lanjut antara lain mengenai hubungan tingkat perhatian orang tua dan persepsi atas kompetensi guru terhadap prestasi belajar Sosiologi. Temuan penelitian menyatakan bahwa kontribusi pengaruh perhatian orang tua dan persepsi atas kompetensi guru secara bersama-sama terhadap prestasi belajar Sosiologi sebesar 40,7 \% , sisanya sebesar 59,3 \% disebabkan oleh faktor lainnya, sehingga perlu dilakukan penelitian lebih lanjut oleh peneliti lain.

\section{DAFTAR PUSTAKA}

Adiputra, Sofwan \& Mujiyati. 2017. Motivasi dan Prestasi Belajar Siswa di Indonesia: Kajian Meta-Analisis. Jurnal KONSELOR, 6 (4): 151.

Adiyanta F.C. Susila. 2019. Hukum dan Studi Penelitian Empiris: Penggunaan Metode Survey sebagai Instrumen Penelitian Hukum Empiris, Adminitrative Law \& Governance Journal, 2 (4): 700. 
Fitriani, Cut. 2017. Kompetensi Profesional Guru Dalam Pengelolaan Pembelajaran Di MTs Muhammadiyah Banda Aceh. Jurnal Magister Administrasi Pendidikan Pascasarjana Universitas Syiah Kuala. 5 (2): 89-90.

Hendriani, Yuli Dan Bustari Muchtar. 2015. Pengaruh Perhatian Orang Tua Dan Konsep Diri Terhadap Prestasi Belajar Siswa Mata Pelajaran Produktif Akuntansi Pada Smk Di Kota Payakumbuh, Jurnal Pendidikan Ilmu Ekonomi. 2 (1): 4-5.

Setyawan, Aris. 2017. Pengaruh Persepsi Atas Kompetensi Guru Dan Peran Orang Tua Terhadap Prestasi Belajar Bahasa Inggris (Survey Pada MTs Swasta Di Kabupaten Tangerang), Jurnal pendidikan STKIP Kusumanegara. 8 (2): 3.

Sormin, Darliana. 2016. Kompetensi Guru Dalam Melaksanakan Dan Mengelola Proses Belajar Mengajar Di Pondok Pesantren Darul Mursyidi Desa Sialogo Tapanuli Selatan. FITRAH. 2 (1): 120-121.

Syafi, Ahmad dkk. 2018. Studi Tentang Prestasi Belajar Siswa Dalam Berbagai Aspek Dan Faktor Yang Mempengaruhi, Jurnal Komunikasi Pendidikan. 2 (2): 117. 